\title{
Yeni Bir Toplumsal Düzenin Doğum Sancısı: İklim Adalet(sizliğ)i ve Hak Temelli Yaklaşımın Önemi
}

\author{
The Travail of a New Social Order: Climate (In)justice and the Significance of \\ the Rights-Based Approach
}

\section{Merve Suzan ILIK BIILBEN*}

$\ddot{O}_{z}:$ İnsanın doğayı tahakküm altına alma ve onu dönüştürme çabası sonucunda iklim değişikliği, insanlığın ve gezegenin 21. yüzyılda karşı karşıya kaldığı en büyük tehdit haline gelmiştir. İklim değişikliğinin etkileri orantısız olarak en yoksul, en marjinal ve en savunmasız kişileri etkilemektedir. Oysa bu kişiler de sorundan en az derecede sorumlu olan ve buna en zor uyum sağlayabilecek durumda olanlardır. Mevcut siyasal araçlar ve uluslararası kurumlar sorunun çözümünde yetersiz kalmaktadır. Bu çalışma, iklim adaletini farklı adalet yaklaşımları çerçevesinde ele almakta; iklim borcunu tarihsel sorumluluklar noktasında irdelemektedir. Makalenin amacı, betimsel bir çalışmayla iklim adaleti tartışmasının günümüz toplumsal düzeninin yapısal unsurları üzerinde var olduğuna dikkat çekerek özgün bir tartı̧̧ma ortaya koymak ve hak temelli yaklaşımın meselenin çeperinden merkezine alınmasının önemini vurgulamaktır. Şimdiye kadar eşi benzeri görülmemiş küresel bir tehdit olarak karşımıza çıkan iklim değişikliği birçok farklı tarafı bir araya getirebilme kapasitesine sahipken, nedenleri ve sonuçları bakımından mevcut ekonomik ve siyasal sistem içerisinde çözümün hala uzağında durmaktadır. Bu noktada iklim adaleti, adil ve yaşanılır yeni bir toplumsal düzenin doğum sancısı olarak görülebilir.

Anahtar sözcükler: İklim Adaleti, İkim Değişikliği, İklim Borcu, Çevresel Adalet, Küresel Adalet

Abstract: As a result of humans attempting to dominate and transform nature, climate change has become the greatest threat which humanity and the planet faces in the 21 st century. The effects of climate change disproportionately affect the poorest, most marginal and most vulnerable people. However these people are those who are the least responsible for the problem and who are least able to adapt to it. Current political instruments and international institutions are insufficient to solving this problem. This study deals with climate justice within the framework of different approaches to justice; climate debt at the point of historical responsibility. Through a descriptive study, this article aims to put forth a distinctive discussion by drawing attention to the fact that the discussion of climate justice is based upon the structural elements of the existing social order. A further aim is to emphasize the importance of relocating the right-based approach from the periphery to the center. Until today climate change, as an unprecedented global threat, has the capacity to bring many different sides together, yet the solution is still far away within the current economic and political system in terms of causes and consequences. At this point, climate justice can be seen as the painful labour for a new social order that is both fair and livable.

Keywords: Climate Justice, Climate Change, Climate Dept, Environmental Justice, Global Justice

\section{Giriş}

Ahlak tartışmalarının temelinde bulunan, dünyanın neresinde yaşarsa yaşasın, hangi milliyetin mensubu ya da dini grubun üyesi olursa olsun, her bireyin refahının ve daha da önemlisi yaşam

\footnotetext{
* Arş. Gör., Akdeniz Üniversitesi, Edebiyat Fakültesi, Sosyoloji Bölümü, Antalya. mervesuzanilik@akdeniz.edu.tr
} 
değerinin diğerleri tarafından eşit derecede önemli görülmesi gerektiği ilkesi iklim adaleti tartı̧̧malarında önemli bir sınavdan geçmektedir. Dahası bu tartışma küresel ekonomik sistemin, çok uluslu şirketler başta olmak üzere uluslararası kuruluşların ve mevcut siyasal düzenin yapısal unsurları üzerine bir de bu bağlamda tekrar düşünmeyi gerektirmektedir. İklim değişikliğini etik bir mesele olarak ele alan iklim adaleti kavramı iklim değişikliğini, nedenleri ve sonuçları bağlamında, özellikle sosyal ve çevresel adalet kavramları ışığında inceler. Bu bakış açısı eşitlik, dünya vatandaşlığı, insan hakları, tarihsel sorumluluklar gibi birçok konuyu ele almayı da gerekli k1lar (Huntjens \& Zhang 2016, 4).

İklim değişikliğinin en önemli özelliklerinden biri gelmiş geçmiş en büyük çevresel tehdit olmasının yanı sıra aynı zamanda uluslararası ilişkiler uzmanlarının da şimdiye kadar tıkandığ en büyük sorunlardan biri haline gelmiş olmasıdır. Çoğu disiplin iklim değişikliğini temelde etik bir konu olarak ele alır lakin, mesele, üzerine gittikçe altından çıkardığı daha geniş ve yerleşmiş anlayışları sarsması nedeniyle yeni paradigmalara ve yeni anlayışlara gebedir. $\mathrm{Bu}$ sebeplerdendir ki, Gardiner de $(2004,555)$ iklim değişikliği konusunda etik filozofların çok az çalışma yapmış olmasının şaşırtıcı olduğunu ifade etmiştir.

Son yıllarda iklim adaletine olan ilgi oldukça artmıştır. 21 Eylül 2014'te iklim adaleti talebi etrafında New York'ta buluşan 300.000'den fazla insan “Halkın İklim Yürüyüşü"ne katılmış, diğer taraftan Google aramalarında iklim adaleti 24 milyona ulaşmıştır (Jamieson 2015, 791). Bu dikkat artışına rağmen, iklim değişikliğinin çeşitli düzeylerde adalet tartışmalarını nasıl etkileyeceği yahut adalet yaklaşımlarının iklim değişikliği sorununun çözümüne ne oranda katk1 sağlayacağı açık değildir. İklim adaleti, iklim değişikliği konusunu ele alan resmi anlaşmaların çoğunlukla kıyısında köşesinde kalmaktadır (Huntjens \& Zhang, 2016, 4). İklim değişikliğinin en savunmasız insanlar üzerindeki yüküne odaklanan iklim adaleti; yerel, ulusal ve uluslararası düzeyde yüklerin daha eşit ve adil bir şekilde dağıtılmasını teşvik ederek savunmasız toplumların haklarını koruma çabasındadır (Das 2016, 413). Bunun yanı sıra, kuşkusuz, iklim adaleti, farklı gruplara ve bireylere farklı şeyler ifade eder ve iklim değişikliğinin adalet kaygıları açısından olası etkileri çeşitli ve karmaşıktır (Huntjens \& Zhang 2016, 1).

İklim değişikliğinin etkilerine maruz kalan grupların kırılganlık derecelerinin oldukça çeşitlilik göstermesi eşitlik ve adalet tartışmalarını kaçınılmaz kılmaktadır. Zira IPCC (Intergovermental Panel on Climate Change-Hükümetlerarası İklim Değişikliği Paneli) uzun zamandır en büyük riski taşıyan bölgelerin zarar görme noktasındaki yüksek kırılganlık seviyeleri nedeniyle düşük enlemlerde konumlanan gelişmekte olan ülkelerde yoğunlaştığını vurgulamaktadır (Mason 2011, 4). Adalet endişeleri iklim değişikliği tartışmalarının, kimin emisyonları ne oranda keseceği, ortaya çıkan zararları kimin ne derece finanse edeceği, süreç yönetişimini kimin ne oranda üstleneceği gibi birçok yönünün merkezinde bulunmaktadır.

Şimdiye kadar eşi benzeri görülmemiş küresel bir tehdit olarak karşımıza çıkan iklim değişikliği birçok farklı tarafı bir araya getirebilme kapasitesine sahipken, nedenleri ve sonuçları bakımından her boyutuyla ele alınması noktasında birçok farklı açıdan adalet tartışmalarını da sürece dahil etmektedir. Tüm dünya için geçerli olan adaleti ifade eden küresel adalet tartışmalarında dahi göz ardı edilen hayvanlar, bitkiler, türler ve hatta Jamieson'un da $(2015,792)$ belirttiği gibi gezegenin kendisi bile iklim değişikliği bağlamında göz ardı edilemez noktaya gelmiştir. Daha dar kapsamlı bir biçimde genellikle devletler arasında ve içindeki adalete atıfta bulunan uluslararası adalet kavramı meselenin önemli bir ayağını oluştursa da çoğu noktada yetersiz kalmaktadır.

Adil bir düzenin nasıl olması gerektiği konusunda en yetkin yaklaşımlardan biri olan Rawls'un 'hakkaniyet olarak adalet' anlayışı adlı çalışmasında ortaya koyduğu 'başlangıç 
durumu' (original position) ve 'bilgisizlik peçesi' (veil of ignorance) adlı iki kuramsal ögeye bu bağlamda değinmek gerekir (Rawls 1971, 17-136). Rawls'a göre "Bilgisizlik peçesi sayesinde, adalet ilkelerinin seçilmesi sürecinde hiç kimse kendi dar çıkarlarını bilmediği için bu çıkarları koruyacak bir ilke savunamayacaktır" (Borovalı 2003, 225). Ancak kalın bir bilgisizlik peçesinin tek taraflı olarak derin uçurumlar yarattığı günümüz dünyasında küresel iklim adaletinden söz etmek de oldukça zordur. Bugün kırılgan ülkelerde yaşanan ve sıklaşan ani sel ve kasırgaların ya da uzun süreli şiddetli kuraklıkların başka ülkelerde refah seviyesini oluşturmak için feda edildiği bilgisi yaygın oranda tek taraflıdır. Rawls'un temel özgürlüklerin hiçbir zaman daha fazla ekonomik getiri elde etmek adına sınırlandırılamayacağı ilkesi iklim adaleti konusunda tarihin çöplüğüne gömülmüştür. Hangi küresel adalet anlayışı, iklim değişikliği sonucu bir bireyin atalarının mezarlarının bulunduğu yerini, yurdunu, evini ve kimliğini geride bırakarak başka topraklara göç etmek zorunda kalmasını açıklayabilir?

Buradan hareketle, makalenin amacı, betimsel bir çalışmayla iklim adaleti tartışmasının günümüz toplumsal düzeninin yapısal unsurları üzerinde var olduğuna dikkat çekerek özgün bir tartışma ortaya koymak ve hak temelli yaklaşımın meselenin çeperinden merkezine alınmasının önemini vurgulamaktır. İlk bölümde farklı adalet yaklaşımları ele alınmakta, iklim politikalarına ilişkin etik ilkelere değinilmektedir. İkinci bölümde iklim adaleti tarihsel sorumluluklar ışığında, tahakküm ilişkileri ve küresel kapitalizm eleştirisi üzerinden tartışılmaktadır. Takip eden bölümde, devlet-birey ilişkisi iklim adaleti bağlamında değerlendirilmekte ve iklim adaleti tartışmalarının ulus devletler arasındaki çözümlerle uluslararası bir mesele olarak sınırlandırılamayacağı üzerinde durulmaktadır. Son bölümde ise hak temelli yaklaşımın önemi vurgulanmakta, ekokıyım ve ortak insan kimliği gibi yeni yaklaşımlar üzerinde durulmaktadır. Makale, insan doğa ilişkisinde artık insanlığın kendini de yeniden konumlandırma mecburiyetinde olduğuna değinilen sonuç bölümüyle sonlanmaktadır.

\section{Hangi Adalet?}

Adalet tartışmalarının dağıtıcı adalet, prosedürel adalet, sosyal adalet, kozmopolit adalet ve ekolojik adalet gibi birçok yönü iklim değişikliği bağlamında ele alınmaktadır. Bunlardan belli başlılarına meselenin hangi yönüne vurgu yaptıklarını anlamak adına burada da değinilecektir.

Temel olarak değerlerin dağılımındaki adalete işaret eden dağıtıcı adalet yaklaşımı küresel kapsamda da belirli bir topluluk ile sınırlı olarak da düşünülebilir (Jamieson 2015, 793). Her adalet ilkesinin uygulaması, bazı ülkelere avantaj sağlarken bazı ülkelere yük getirdiği için, "taraflar kendi çıkarlarına göre adaleti ve adaletin boyutlarını tanımlayarak, adalet kilıfi içinde kendi ulusal çıkarlarını” (Demirci 2013, 185) savunmaktadır. Bu bağlamda, küresel sera gazı salımlarını dengelemenin maliyetleri, bu maliyetlerin her ülke için ne kadar değişkenlik gösterdiği, rekabet avantajlarını nasıl etkileyeceği, fosil yakıta dayalı ekonomik düzen göz önüne alındığında, dağıtıcı adalet yaklaşımı daha çok önem kazanmaktadır. Kazançların ve yüklerin dağılımının değerlendirilmesini içeren dağıtıcı adalet anlayışı açısından iklim politikası tartışmalarında değinilen ilkelerin başlıcaları şu şekildedir (Schmidt 2012, 6):

- Atmosferi kullanmak için kimsenin diğerinden daha güçlü bir iddiasının olamayacağını savunan eşitlik ilkesi,

- Tarihsel karbon salımının iklim üzerindeki etkilerine vurgu yapan dededen kalma (grandfathering) ilkesi,

- Diğer koşullara bakılmaksızın, temel insan hakları söz konusuyken yoksul ülkelere ve insanlara yardım sunmanın manevi gerekliliği üzerinde duran ihtiyaç ilkesi,

- Sorunun nedenlerine odaklanan ve iklim politikalarının maliyetlerini ele alarak 
bundan sorumlu kişilerin de sorunu çözmek için önlem almalarını talep eden sorumluluk ilkesi,

- Sorumluluk meselesiyle uğraşmak yerine emisyon azaltma yeteneği gibi aktörlerin belirli çabaları devralma kapasitesine odaklanan ödeme kabiliyeti ilkesi,

- Kuşaklararası ilişkilere odaklanan, gelecek nesillerin temel ihtiyaçlarını karşılama kabiliyetini korumayı talep eden kuşaklararası temel ihtiyaçlar ilkesi,

- Kuşaklar arası adaletin gelecek nesillere verilecek doğal, insani, teknolojik ve finansal sermayenin toplam stokunu artırmak (veya en azından istikrara kavuşturmak) ile ilgili olduğunu öne süren pozitif tasarruf ilkesi (Schmidt 2012, 6).

Tüm bu ilkeler arasında, iklim adaleti kavramını açılamak için kullanılan en uygun ilkeleri belirlemek amacıyla 2015 yılında Avustralya'da gerçekleştirilen Delphi araştırmasının sonuçlarına göre ise kuşaklararası iklim adaleti kavramı küresel iklim değişikliği anlaşması için temel kavram olarak kabul edilirken, bunu dağıtıcı adalet ve ödeme kapasitesi ilkesinin takip ettiğ sonucu ortaya çıkmıştır. Araştırmanın beklenmedik bir bulgusu prosedürel adalete yapılan vurguyken en şaşırtıcı sonucu ise hak temelli yaklaşımın çok düşük bir ağırlığa sahip olmasıdır (Guglyuvatyy 2017, 61). ABD, Çin ve Hindistan basınındaki iklim politikası tartışmalarını analiz eden başka bir çalışmanın sonucu da benzer şekilde dağıtıcı adalet kararlarındaki tercihlerin oldukça farklı olduğunu bunun da uluslararası düzeyde uyumlu eylemi engelleyebileceği ve gelecekteki ve bugünkü savunmasız insanların ortak çıkarlarını tehlikeye atabileceğini göstermektedir (Schmidt 2012, 20).

Dünya Doğa ve Doğal Kaynakları Koruma Birliği tarafından, iklim değişikliği için etik yükümlülüklere ulusal uyum konusunda kamuya açık bir kayıt geliştirerek, ulusal iklim politikası üzerinde kamusal etik incelemesini derinleştirmek amacıyla bir araştırma projesi gerçekleştirilmiştir (Brown \& Taylor, 2014). Projenin 2014 y1lı araştırma raporunda 15 farklı ülkenin iklim değişikliği bağlamında etik ve adalet konularına yaklaşımı incelenmiştir. Rapora göre; Bolivya, Güney Afrika ve Japonya gibi bazı ülkeler iklim politikalarının etik ilkeler tarafından yönlendirilmesi gerektiğini kabul etmekte ancak ulusal politikalarını belirlerken bunun niceliksel olarak nasıl gerçekleşeceğini açıklamamaktadır. Diğer taraftan Birleşik Devletlerin de dahil olduğu bazı ülkeler ulusal iklim politikalarını belirlerken etik ve adalet meselelerini dikkate alma gereği duymamaktadır. İtalya, Avustralya ve Yeni Zelanda gibi bazı ülkelerde iklim değişikliği yeterince kamusal ve politik ilgi görmemekte ekonomik ve mali konulardan sonra gelmektedir. Güney Kore gönüllü emisyon azaltma hedeflerini ortaya koyarak küresel yeşil pazarda lider olmak isterken, Hollanda temiz teknolojiler için uygun fiyatlar ortaya koymaya, temiz enerji tedariki için firsatlar sunmaya çalışmaktadır. Diğer taraftan Japonya iklim değişikliğine çok farklı bir etik bakış açısıyla yaklaşarak düşük tüketimli yaşam tarzına vurgu yapmakta ve doğa ile uyum içinde yaşayarak Düşük Karbon Topluluğu Oluşturma politikası yürütmektedir. Bolivya ise oldukça istisnai bir durum teşkil ederek, ülkeler tarafından ulusal sera gazı emisyonlarında derin kesintiler yapılmasını gerektiren etik gerekçelere güçlü ve açık bir şekilde dayanmakta ve Dünya Ana için oluşturduğu risk nedeniyle 2 derecelik 1sınmayı kabul edilemez bulmaktadır. Avustralya'nın raporu ise ahlaki liderlik ilan etmenin siyasi süreci müzakere etme noktasında yeterli olmayacağını göstermekte, kamu taahhüdünün sürdürülmesi, çapraz parti desteğinin oluşturulması ve muhalefetin kazanılmış menfaatlerinin yönetilmesinin de kritik öneme sahip olduğunu ortaya koymaktadır. Rus raporu ise, iklim değişikliği konusunda şüpheli olan çok sayıda hükümet bilimcisinin görüşleri nedeniyle benzersiz bir bakış açısı sunmaktadır. Sonuç olarak, hemen hemen tüm ülke raporları "adil paylaşım" retoriğinin ötesine bakma ihtiyacını, adil paylaşımın gerçekte ne olduğunun, nasıl hesaplanacağının ve gerçek anlamda hangi 
düzeylerde kesintiye neden olacağının sorulması gerekliliğini ortaya koymaktadır (Brown \& Taylor 2014, xxi-xxvii).

Bir diğer husus kozmopolit adalet anlayışı açısından iklim değişikliğinin sonuçlarını değerlendirme gerekliliğidir. Uluslararası adalet, adalet için pratik bir temel olarak ulusal sınırları görürken, kozmopolit adalet bunun pratik avantajını kabul eder ancak meseleye sadece ulusal sınırlar açısından yaklaşmanın yanlış ve yetersiz olduğunu vurgulayarak bireyleri "nihai değerlendirme birimleri" olarak alır (Bell 2010, 476). Ülke içi adalet tartışmasında olduğu gibi, küresel alanda da analiz birimini kişi olarak alan kozmopolit yaklaşıma göre bireyin mensubu olduğu ırk, etnik grup, milliyet ya da dinden kaynaklı durumlar adalet ile ilgili tartışmaları bağlamaz (Borovalı 2003, 231). Bu noktada, Gaia'nın da aynı kozmopolit adalet anlayışı gibi devlet, millet, ırk ayırt etmeden intikamını almakta (Lovelock 2006) olduğunu düşünebiliriz. Ne var ki suçu işleyen geçmiş karbon salımları nedeniyle büyük oranda sanayileşmiş toplumlarken, intikamın ilk alındığ 1 yerler kırılgan durumda bulunan az gelişmiş toplumlardır. İklim değişikliğinin etkileri ilk olarak büyük oranda az gelişmiş ülkelerde ve savunmasız toplumlarda görülmeye başlamasaydı, yine adalet kaygısından bu kadar uzak ve aymaz bir şekilde davranılır mıydı? Yoksa iklim değişikliğinin sonuçlarından etkilenenler öncelikle erkek, beyaz, aristokrat yahut kuzeyli olsaydı küresel adalet kaygısı çok daha büyük mü olacaktı?

Benzer şekilde "hem gelişmiş hem de gelişmekte olan ülkelerdeki varlıkl insanların, iklim değişikliğinin olumsuz etkilerine karşı en savunması durumda olan dünyaya, yoksul ve marjinalleştirilmiş insanlara karşı olan sorumluluklarını vurgulayarak (Huntjens \& Zhang, 2016, 6)" meselenin sosyal adalet yönlerine daha az odaklanılırken, acil hazırlık gerektiren yönlerine daha çok odaklanıldığ 1 ve bir araştırma konusu olarak iklim adaletinin bu nedenle kısır kaldığ 1 görülmektedir (Preston et al. 2014, 3). Diğer taraftan çevresel adalet de koruma davranışının ve yasama kararlarının ayrılmaz bir parçasıdır. Reese'e göre $(2015,16)$ "çevresel adaleti grup temelli süreçlerin bir fonksiyonu olarak anlamak, iklim değişikliği örtüsünde insanlığın yüz yüze olduğu ortak kadere, insanliğın paylaştığl ortak hedeflere, gayretlere ve kolektif etkinliğe odaklanmaya yardımcı olabilir". Bunun da ötesinde mesele insan savunmasızlığ 1 ve biyolojik çeşitlilik kaybı arasındaki karmaşık bağlarla da iç içedir. Dahası Steele ve arkadaşlarının da $(2015,121)$ belirttiği gibi, meselenin boyutları disiplinlerarası bir yaklaşımla, insan savunmasızlığı ve biyo-çeşitlilik kaybı arasındaki karmaşık bağların bütünleştirilmesini ve yeni sürdürülebilirlik formlarını gerektirmesi nedeniyle eko-sosyal adalet ilkeleriyle de bütünleşik bir yapı sergilemektedir.

\section{Tarihsel Sorumluluklar}

İklim adaleti perspektifi, temelinde, emisyon konsantrasyon dağılımında en az katkıya sahip olanların bunun olumsuz etkilerine en yüksek düzeyde maruz kalanlar olduğu gerçeğine dayanmaktadır. Diğer bir ifadeyle, iklim adaleti savunucuları iklim değişikliğini birçok farklı alanda eşitsizlikleri derinleştiren etkisiyle birlikte bir temel haklar meselesi olarak ele almaktadır. Dünyadaki uluslararası güç ve varlık birikimi iklim değişikliği bağlamında ele alındığında da genel bir kuzey-güney bölünmesi karşımıza çıkmaktadır. Bilindiği gibi yaygın kanı, iklim değişikliğinden küresel kuzeyin büyük ölçüde fayda sağlarken bunun sonuçlarından nispeten etkilenmediği, buna karşılık küresel güneyin iklim değişikliğine ne katkıda bulunmuş ne de ondan fayda görmüş olmasına rağmen, olumsuz etkilere karşı en savunmasız durumda olan bölge olduğudur. Dolayısıyla iklim adaleti savunucularına göre, küresel kuzeyin neden olduğu sosyo-ekonomik ve ekolojik krizler nedeniyle küresel güneye "iklim borcu" vardır (Mckinney \& Fulkerson 2015, 294). Bu bağlamda, her ülkenin karbon ayak izi yahut dünya karbon metabolizmasının toplu aşırı tüketimine olan göreceli katkılarına oranla ekolojik ayak izi gibi araştırma- 
ları yapan Küresel Ayak İzi Ağı vb. birçok girişimi gözlemlemek mümkündür. (Mckinney \& Fulkerson 2015, 296). Ancak Shue'nun vurguladığ 1 üzere, tüm ihtimallerin nicel bir analizini istemenin pek makul olmadığı ve tek başına iklim değişikliği ekonomisinin uluslararası sözleşmelerde eylem için iyi bir rehberlik sağlamadığı da görülmektedir (Martinez-Alier 2014, 383). Hepsinden önemlisi, belirsizlik ve sinırlılıkların eylemsizlik için bir sebep olamayacağ tartışmaların pazarlık konusu edilmemesi gereken haklar odağından uzaklaşmaması gerektiğidir.

Daha önce de belirtildiği üzere, iklim adaleti küresel adalet tartışmalarından bağımsız düşünülemez. Dahası ekonomik, çevresel ve sosyal yönleriyle iklim adaleti bugün küresel adalet tartışmalarını büyük oranda etkilemektedir. Küresel adalet tartışmalarının temelinde nasıl bir küresel adalet kuramının benimsenmesi gerektiği ile ilgili anlaşmazlıkların yatıyor olması (Borovalı 2003, 220), iklim adaleti tartışmalarının da temelini oluşturmaktadır. Gelişmiş yahut sanayileşmiş ülkelerin bu duruma nasıl geldikleri göz önünde bulundurulduğunda, iklim adaletinin sağlanmasındaki yükümlülüklerinin neler olduğu, iklim adaletinin hangi şartlarda yerine geleceği sorusunun da yanıtını verir. Nozick'in ifade ettiği gibi adalet ilkeleri tarihsel bir boyut içerecek ise, yani dağılımın adil olup olmadığı kişilerin ne yaptığına bakarak belirlenecekse (Borovalı 2003, 244), tarafların yükümlülükleri bu konunun kilit taşıdır. İklim değişikliğinin geri döndürülemez noktasına ulaşmamak adına, farklılaşmış sorumluluklar ilkesinin uygulanmasında adalet ancak sanayileşmiş ülkelerin karbon ayak izlerine çarpıcı sınırlamalar getirmelerinin yanı sıra savunmasız topluluklara adaptasyon desteğinin sağlanmasındaki öncelikli rollerin yerine getirilmesi ile sağlanabilir (Mason 2011, 6). Zira, ortak fakat farklılaşmış sorumluluklar ilkesi iklim yönetiminin iki farklı yönünün nasıl dengelenmesinin amaçlandığını göstermektedir: ortak olan tüm ülkelerin birlikte yapmaları gereken şeyler iken, farklılaşmış olan beklenen çabanın ülkeler arasında bazı adalet kavramlarına göre nasıl çeşitlilik gösterdiğidir (Lahn 2017, 2).

Tarihsel sorumluluk ve maliyetlerin nasıl üstlenileceği konusunda da pek çok yaklaşım mevcuttur. Godard iklim borcunun geri ödenmesindeki israrın sadece zengin ülkeleri rahatsız etmediğini aynı zamanda uluslararası müzakerelerin başarısı için de verimsiz olduğunu savunmaktadır (Martinez-Alier 2014, 382). Diğer taraftan Shue; iklim borcunu, zengin ülkelere bask1 yapmak için kullanmanın küresel Güney'den müzakerelere en iyi katkı olacağını savunanlara karşı çıkmakla birlikte, enerji yoksulu ülkelere karbon dış1 enerji kaynakları için verilecek sübvansiyonlar1 desteklemektedir (Martinez-Alier 2014, 382).

Küresel iklim adaleti konusunda daha kapsamlı bir teori sunan Vanderheiden $(2008,222)$ ise, 'iklim sözleşmesinde ifade edilen idealler üzerinden' adaletin, iki temel normatif kriter olan 'eşitlik ve sorumluluk' şeklinde anlaşılabileceğini ileri sürer. Ayrıca, 'emisyon azaltma çabaları ile ilgili masraflar' ve 'değişen iklim koşullarına adaptasyon maliyetleri' gibi dağıtılacak 'maliyet veya yükü' iki kategoriye ayırır. Emisyon paylarının tahsisi için 'eşitlik kriterinin' ve tazminat ve uyum maliyetlerinin tahsisi için 'sorumluluk kriterinin' rehberlik etmesinin uygun olduğunu ileri sürer (Vanderheiden 2008, 222). Diğer bir ifadeyle, emisyon izinleri (az çok) kişi başına eşit olarak dağıtılmalı ve adaptasyon ve tazminatın finansal maliyetleri, sera gazı emisyonları için tarihi sorumluluk temelinde dağıtılmalıdır (Bell 2010, 478). Vanderheiden'ın tarihsel sorumluluk tartışması cehalet, belirsizlik ve anlaşmazlık üzerinde durması nedeniyle bir başlangıç noktası olarak kabul edilse de gelişmiş ülkelerin gelecekteki emisyon oranlarının gelişmekte olanlardan daha az olması gerekliliği ya da gelişmekte olan ülkelerin de mecbur kaldığı azaltma maliyetlerini finanse etmeleri gerekip gerekmediği konuları üzerinde durmamaktadır.

Tüm bu tartışmaların yanı sıra Harris ise (2010, 9-10), ne kadar farklılık arz ederse etsin yapılması gereken şeylere ilişkin teorilerin sonuç olarak uyum içerisinde olduğu, dolayısıyla 
önemli olanın siyasetçi, diplomat, milletvekili, aktivist olmayan gerçekçi dünyada yaşayan insanları ikna edebilecek 'geniş, nispeten açık ve basit kavram ve argümanlar' üretmek olduğunu savunarak küresel iklim adaletinin haklılı̆̆ üzerinde durmaktadır.

Ortaya konan tüm girişimlerin, müzakerelerin ve anlaşma çabalarının başarısızlığa uğramasını, sanıldığı gibi dünya liderliğinden yoksun olmaya değil, kapitalist sistemin gezegendeki hayat üzerinde artan tehditlere karşı önlem alabilme yetisinden yoksun olmasıyla ilişkilendiren Foster $(2012,41)$ ise, bu bağlamda doğa bilgisi ve kapitalizmin sınırları ve onları aşma yollarının hayati önem arz ettiğini belirtmektedir.

Gemi azıya almış küresel kapitalist ekonomi, gezegeni ve insanlığ kendi ile birlikte büyük bir girdabın içerisine sürüklemektedir. Radkau'nun da $(2017,421)$ belirttiği gibi bugün, tarihsel çevre bilincine sahip olmak, mevcut ekonomik sistemin geçmişte bir emsaline rastlanmayacak bir biçime sahip olduğunu görmek anlamına gelmektedir. Oluşması milyonlarca yıl sürmüş olan fosil yakıtları hesapsızca yakmanın sonuçları idrak edilmeden, atmosfer karbon gazıyla doldurulmuştur. Sürdürülebilir olmayan bu ekonominin dönüm noktası kömür çağına geçişe kadar uzansa da, 20. yüzyılda dizginlerini koparmış ve çok yakın tarihte palazlanmıştır. Bu nedenle, yakın dönem tarih çalışmalarına da tam olarak oturtulamayan bu meselenin yeni ve bir o kadar da elzem olan tarafi ise önü alınamayan bir hızda ilerlemesi ve her yere uzanan küresel niteliğidir (Radkau 2017, 421).

Yaşanan ekolojik kriz bağlamında küresel iklim değişikliğine karşı verilecek mücadelenin neticede küresel kapitalizmin çokuluslu şirketlerine karşı verildiği de bir gerçektir. Zira "kapitalizm, doğa anayı hammadde kaynağına, insanları tüketicilere ve üretim araçlarına dönüştüren sistem olarak açıkça halkın karşısındadır" (Atay 2016, 13-14). İklim değişikliği krizinin çözülememesinin temelinde de bu gerçek yatmaktadır. Yeni kurumsal biçimleriyle, siyasi ve ekolojik içerimleriyle yeni bir düzeye ulaşan küreselleşme çağında (Kovel 2017, 99), gündelik tüketim alışkanlıklarının değiştirilmesine dayalı yeşil kapitalizm ya da sermayenin yeşil ekonomisi tek başına kati suretle iklim krizinin çözümü olamayacaksa da bu anlamda yaşanacak köklü bir değişimden bağımsız hiçbir ideal adalet perspektifi yahut uluslar üstü bir girişim de kendi başına meseleyi çözüme ulaştıramayacaktır. Diğer bir ifadeyle:

$$
\begin{aligned}
& \text { “... şunu kesin olarak kabul edebiliriz: Kenarını köşesini düzeltmek } \\
& \text { yerine ekolojik krizi tamamen çözmek ile devasa sermaye havuzlarının, } \\
& \text { bu havuzların ortaya çıkardı̆̆ kuvvet alanının, bunların bağlantıl oldu- } \\
& \text { ğ yer altı suç dünyasının ve bütün bunlara ek olarak ulus-ötesi burju- } \\
& \text { vaziyi oluşturan seçkinlerin varlığı birbiriyle hiçbir biçimde bağdaşmaz. } \\
& \text { Krizi tümüyle çözmeyince de, başka bir mitik yaratığın hayaletinin, baş- } \\
& \text { ları kesildikçe çoğalan dokuz başl yılanın hayalinin bize musallat olma- } \\
& \text { sına izin vermiş oluruz” (Kovel 2017, 187). }
\end{aligned}
$$

Vurgulanması gereken bir diğer önemli nokta iklim krizinin iklim adaleti, iklim adaletinin tarihsel emisyon sorumlulukları, emisyon sorumluluklarının da emperyalizmin ve sömürgeciliğin tarihsel mirası üzerine oturduğu gerçeğidir (çevre tarihinde sömürgeciliğin önemi için bakınız: Radkau 2017). Sanayileşmiş ülkelerin neden olduğu süreçlerden kaynaklanan bir iklim borcu vardır ve bu borç ödenmediği her gün katlanarak dağ gibi büyümekte ve telafisi giderek zor hale gelmektedir (bu açıdan Karayipler özelinde yapılan bir analiz için bakınız: Sealey-Huggins 2017).

$\mathrm{Bu}$ bağlamda benzeri görülmemiş bir iklim değişikliği tehdidiyle karşı karşıya olan en dezavantajlı grupların durumlarına ilişkin kavramsal zorluklara işaret eden Mason $(2011,8)$, 
Filistin örneğinde yüksek iklim hassasiyetine sahip bir nüfusun nasıl uluslararası iklim endişelerinin gerisinde kalabildiğini göstermekte, tarihsel miras sorgulanmaksızın girişilen bir etik arayışının nasıl beyhude kalabileceği böylelikle gözler önüne serilmektedir. Benzer şekilde, Amerika'da "tarihsel sorumluluğun" konuşulmaması gereken bir şey olduğunu ve iklim borcunun ne olduğunu BM Bolivya Büyükelçisi Angelica Navarro'dan öğrendiğini dile getiren Kanadalı Klein, tam da bu nedenle kitabında yoksulların ve yerli halkın çevreciliğinin, Büyük Yeşil organizasyonların çevreciliğinden çok daha önemli olduğuna inandığını ifade etmektedir (Martinez-Alier 2014, 384). Bu bağlamda, iklim adaleti tartışmalarını derinleştiren, iklim değişikliğinin yaşlılar, kadınlar, çocuklar, düşük gelir grupları, kiracılar, kentlerin marjinal bölgelerinde yaşayanlar, siyahi bireyler, hali hazırda göç riskiyle karşı karşıya olanlar gibi birçok dezavantajlı grup üzerindeki etkilerine ilişkin çalışmalar giderek artmaktadır (bk. Preston et al., 2014; Steele et al., 2015; White-Newsome 2016; Das 2016; Bond 2016; Huntjens \& Zhang 2016).

\section{Ulusların Sınırları, İklimin Sınırsızlığı}

İklim adaleti kavramı, devletlerarası sorumluluklar ve iklim değişikliği üzerine Kuzey-Güney ilişkileri üzerine yapılan uluslararası tartışmaların bir parçası olarak ortaya çıkmış olsa da şu ana kadar iklim adaletinin uluslararası müzakerelerin ötesinde ne ifade ettiği, çeşitli aktörlerin iklim adaletine yönelik taleplerinin nasıl ölçeklendirilebileceği konuları bir temelden yoksundur (Fisher 2014, 80).

İklim değişikliğini bireylerin değil devletlerin arasındaki bir adalet tartışması olarak düşünmek daha kolay olabilir. Bu yaklaşım iklim müzakerelerinin devlet merkezci bakış açısının da temelindedir. Ne var ki, iklim değişikliğinin kuzeyin zengin ülkeleri ile güneyin yoksul ülkeleri arasındaki adaletsizlik eylemi olduğu yargısı tüm akla yatkınlı̆̆ına rağmen devletler arasındaki adaletsizliğin bazı merkezi özelliklerini göstermez ve geleneksel küresel adalet teorilerinin başa çıkma noktasında donanımsız olduğunu gösteren kanıtlar sunar (Jamieson 2015, 803): Birincisi, yüksek karbon salımına sahip bazı ülkeler emisyonların olumsuz etkisini hala reddetme yoluna giderken bazı ülkeler hasarları kabul ederek emisyonları azaltmak ve bundan muzdarip olanlara yardım etmek için politikalar üretmektedir. Ancak Jamieson'ın da belirttiği gibi bu durum devletler arası adalet tartışmaları açısından bakıldığında tuhaf bir durum oluşmaktadır; çünkü bir tarafta bir ülke haksız yere başka bir ülkeyi istila ettiği ama bundan haberi olmadığını söylerken, diğer tarafta ise bir başka ülke aynı ülkeye verdiği zararı telafi etme çabası içindeyken bir taraftan da buna neden olan politikaları sürdürme yoluna gitmektedir. İkinci bir farklılık, devletler arasındaki adaletsizlik paradigmalarının, kasıtlı olarak hasarın yol açtı̆̆ 1 cezalandırmayı içermesi ve iklim değişikliğinde böyle bir şeyin söz konusu olmamasıdır. Üçüncü bir fark, atmosferin ulusal sınırlardan bağımsız olması ve karbon molekülünün iklim üzerinde her yerde aynı etkiye sahip olmasıdır. Nerede yaşarlarsa yaşasınlar iklim değişikliğine zenginler neden olmuştur ve ondan, her nerde yaşarlarsa yaşasınlar yoksullar etkilenmektedir. Bu nedenle, iklim değişikliğine en çok katkıda bulunan ve en çok zarar gören insanlar farklı oranlarda olsa da dünyanın tüm ülkeleri arasında dağılmış durumdadır. Dördüncü fark ise, iklim değişikliğini küresel adaletin sıradan sorunlarından ayıran risklerin niteliği ve buna bağlı zamansal aciliyet ile ilgilidir (Jamieson 2015, 803-805).

Jamieson'ın üzerinde durduğu üçüncü fark iklim adaleti tartışmalarında büyük bir yer kaplamaktadır. Zira bölünmenin yalnızca gelişmiş ve gelişmekte olan ülkeler arasında değil aynı zamanda varsıl ve yoksul insanlar arasında da olduğu görülmektedir. Bu nedenle devletlerden ziyade insanlara odaklanmanın önemi vurgulanmaktadır (Huntjens \& Zhang 2016, 4). Temelde kozmopolit adalet perspektifinden beslenen bu anlayışta zenginler sorumluluk sahibi ajanlar 
olarak tanımlanmakta ve dünyanın her yerinde varlıklı bireylerin iklim değişikliği ile mücadele masraflarını ödemesi gerekmektedir. Ulus devlet, hesap verme sorumluluğu, demokratik kontrolün sağlanması açısından ana çerçeve olmayı sürdürse de ulus devletlerin rekabetçi dezavantajlardan korkmaları nedeniyle tek taraflı taahhütlerin imkânı oldukça tartışmalıdır.

Zira, iklim adaleti tartışmalarını, ulus devletler arasındaki çözümlerle uluslararası bir mesele olarak sınırlama yoluna gitmek, toplumsal hareketler ve yerel çözümler açısından da bir kısırl1ğa neden olma tehlikesi taşımaktadır (Fisher 2015, 80). Çözümü ulus devlet tekelinden almak savunmasız durumda bulunan bireyler ya da topluluklar için daha adil çözümler sunabilecek farklı alanların yaratılmasını sağlayabilir. Tam da bu açıdan önemli bir temsil teşkil eden örneklerden bazılarının La Via Campesina tarım hareketinin ve İklim Değişikliği Üzerine Uluslararası Yerli Halklar Forumu'nun kendi çerçevelerini geliştirmek ve hak temelli politikaları savunmak için gerçekleştirdikleri çalışmalar olduğu söylenebilir (bk. Claeys \& Pugley 2016). Diğer taraftan birey olarak karbon salım oranında ve iklim politikalarının düzenlenmesinde neredeyse hiçbir etkisi olmayan bir Amerikalı da iklim değişikliğinin olumsuzluklarından etkilenmekte ve böylelikle adalet tartışmalarına dahil olmaktadır. Jamieson'ın Katrina Kasırgası sonrası evsiz kalan yoksul New Orleans sakinleri örneği oldukça can alıcıdır (Jamieson 2015, 794). Sweetman ve Whitmarsh'in da belirttiği gibi $(2016,217)$, güç ve statüye sahip olan toplumlar ve gruplar etkileri ve kaynakları daha fazla olduğu için iklim değişikliği ile mücadelede daha büyük bir etkiye sahiptirler.

Dolayısıyla soruna neden olanların kendileri olduğunu ve adil olmalarının tek yolunun çevresel bilinçle harekete geçmeleri olduğunu bireylerin onlara hissettirmesi gerekmektedir. Ve gayet tabii, eylemlerin etik olarak adil olması, iklim değişikliği ile mücadele etmek için ahlaki psikolojimizi kuvvetlendirmede etkili bir yol olabilir (Sweetman \& Whitmars 2016, 218). Harris'in $(2010,123)$ vurguladığı üzere, “yüz milyonlarca varlıklı (orta sınıf ve üst sınıf) insan şimdi gelişmekte olan ülkelerde yaşamakta ve gelişmiş ülkelerin insanları kadar ve bazen de daha fazla tüketme gücüne sahiptir". Bu nedenle Çin, Hindistan, Brezilya, Endonezya, Meksika ve diğer ülkelerdeki yeni tüketiciler iklimle ilgili görevlerden muaf tutulmamalı, azaltım, adaptasyon ve tazminat finansmanı gibi maliyetlere yöneltilmeleri gerekmektedir (Bell 2010, 476477).

Buradaki niyetin gelişmiş dünyanın mazur görülmesi değil, her yerde (gelişmekte olan ülkelerdeki varlıklılar da dahil olmak üzere) "zengin ve yetenekli" olanlardan bir eylem talep edilmesini sağlamak olduğunu unutmamak gerekmektedir (Bell 2010, 477). Özellikle uygulama noktasındaki tüm kuşkularına rağmen bu yaklaşım gelişmiş ülkelerdeki sorumluların taşın altına ellerini daha hızlı bir şekilde koymalarını sağlamak adına önemlidir. Tüm bu görüşler tarihsel sorumlulukların göz ardı edildiği anlamına da gelmemektedir, zira bu gibi üst düzey yönetişim gerektiren süreçlerde herkesin kendi payına düşen ile alakadar olması temel motivasyon kaynağıdır. Sonuç olarak, antropojenik iklim değişikliği, bireyler arasındaki adaletsizliğin ve devletler arasındaki adaletsizliğin bazı özelliklerine sahip olsa da hiçbirine tam olarak uymamaktadır. Bunun en büyük nedeni, herkesin iklim değişikliğine -bireyler, şirketler, hükümetler- katkıda bulunması ve herkesin risk altında olmasıdır (Jamieson 2015 806).

\section{Hak Temelli Yaklaşımların Önemi}

İklim adaletinin, aslında açılması istenmeyen pandoranın kutusu olduğunu söylemek mümkündür. Zira, iklim politikasının iklim adaleti çerçevesinde yer alması neo-liberal küreselleşmenin bağlı olduğu eşit olmayan toplumsal ve çevresel ilişkilere dikkat çekmekte (Chatterton et. al. 2012) ve bu da bazı politika yapıcıların ve akademisyenlerin adaletle ilgili soruları 'müzake- 
releri bozabilecek' bir dikkat dağıtıcı olarak görmelerine ve bu tartışmadan kaçınmalarına neden olmaktadır (Klinsky et. al. 2017 akt: Lahn 2017, 13).

Adalet tartışmalarının yanı sıra, hak temelli yaklaşımların meselenin daha da uzağında kalmasının temel sebeplerinden biri iklim değişikliğinin disiplinlerarası izlediği süreçtir. Önceleri sadece meteorolojinin konusu olan iklim değişikliği sonradan fen bilimlerine dahil olmuş ve sosyal bilimlerin de konusu halini alması görece yeni olmakla birlikte, tamamen olmasa da büyük oranda ekonomik tartışmaların nesnesi, refah temelli çözümlerin muhatabı olagelmiştir. Diğer taraftan hak temelli yaklaşımlar açsından, her ne kadar devletler uluslararası anlaşmalara taraf olsalar da uygulama noktasında çoğu zaman sıkıntı yaşanmaktadır. Sürece rehberlik edecek operasyonel bir çerçevenin bulunmaması ise bir diğer sıkıntıdır. Bu da farklı algılamalara neden olarak ne yapılması ve nasıl yapılması gerektiği konusunda uzlaşmaya varılmasını zorlaştırmaktadır. Bununla birlikte, bu yaklaşıma dayalı bir kapasite geliştirebilmek, kuşkusuz önemli miktarda zaman, uzmanlık, bilgi ve finansal kaynak gerektirmesi sebebiyle de zor bir seçenek olarak görülmektedir.

Tüm bunlar hak temelli yaklaşımların önemini ve aciliyetini azaltmamaktadır. Aksine bu yaklaşımların kültürel ya da yerel değerlerle birleştiği takdirde çok özgün örnekler ortaya koyabileceğini Bhutan, Ekvator ve Bolivya Anayasaları göstermiştir (bk. Uprimny 2012; Özlüer vd. 2013). Meselenin özünde bir temel insan hakları meselesi olduğu gerçeğinden ne kadar uzaklaşmamayı başarabilirsek, çözüme de o kadar yakınlaşabiliriz. Çünkü iklim değişikliği birçok insanın temel haklarını ihlal edecekken ya da bu hakların altını oyarken, mücadele etmek için harekete geçmekte çok yavaş davranılmaktadır. 'Kirletilmemiş hava' ve 'kirletilmemiş su' gibi temel çevresel haklardan hareketle istikrarlı bir iklim, insanların temel haklarından biriyse ve bu haklar iklim değişikliği ile birlikte tehdit altındaysa, bu haklara ilişkin görevlerin nasıl tahsis edileceğinin (Bell 2010, 476) yani iklim adaletinin nasıl sağlanacağının araştırılması oldukça mühimdir. Bu bağlamda, "uluslararası insan hakları hukukunu içeren, ilkelere ve kararlara yol gösteren küresel insan hakları rejimi, tüm paydaşların, özellikle de nüfusun savunmasız kısımlarının, çözüm yollarına ve aynı zamanda iklim değişikliği politikası belirleme sürecine tam katılım hakkı gösterebilmesini sağlamalıdır" (Huntjens \& Zhang 2016, 23). Bu bağlamda iklim ve koruma görüşmeleri için ortak bir zemin bulmaya yönelik yolun ortak bir insan kimliğinden geçtiğini iddia eden Reese (2015, 4-5), ortak insan kimliği anlayışının, ahlaki açıdan doğru veya yanlış olan konusundaki anlaşmazlığın üstesinden gelmeye yardımcı olabileceğini, böylece çevresel adalet ilkeleri üzerine toplumsal olarak paylaşılan görüşler için bir temel oluşturacağını ifade etmektedir.

İklim değişikliği insanlığın geleceği ve gelecek kuşakların barış içinde yaşaması açısından muazzam bir tehdittir. Bu açıdan iklim değişikliğinin bir eko-kıyım türü olarak kabul edilmesi gerektiği, eko-kıyımın da uluslararası hukukta barışa karşı işlenmiş bir suç olarak tanımlanması gerektiği sesleri de yükselmektedir (Huntjens \& Zhang 2016, 22). Kuşkusuz eko-kıyımın kabulü iklim değişikliği konusundaki eylemsizliklere bir çözüm olarak en azından ihlal edilen hakların korunması için bir mekanizma sağlayarak devletler, bireyler ve şirketlere karşı yaptırımlarla iklim adaletini geliştirmeye yardımcı olabilir. Gelgelelim, mevcut, geçerli ve ümit vadeden anlaşma olan Paris Anlaşması'na taraf olan hükümetler, sorumluluklarını yerine getirmedikleri takdirde vatandaşlarının nasıl tepki vereceği de oldukça önemlidir. Bu noktada Caney'nin $(2016,24)$ toplumlara yönelik somut eylem planlarının çizilmesi gerektiği vurgusu da oldukça önemlidir.

Taraflar konferansı süresince iklim değişikliği etkileri bağlamında bu küresel yükün uluslar arasında adaletli paylaşımı temel tartışma konusu olsa ve geniş parametrelerle ortaya konulsa 
da, iklim adaletinin sağlanması noktasında kayda değer netliğin yakalanamamış olması gelişmiş ve gelişmekte olan ülkelerin eylemsizliklerinde, yardımların niteliği ve kapsamındaki belirsizliklerde kendini göstermektedir. Zira,

"çeşitli devlet partilerinin hafifletme çabalarına ya da adaptasyon yardımına ne kadar katkıda bulunması gerektiği konusunda zengin bir akademik literatür vardır, ancak Birleşmiş Milletler İklim Değişikliği Çerçeve Sözleşmesi (UNFCCC-United Nations Framework Convention on Climate Change) gibi politika gelişstirme kurumlarının işleyişi arasındaki bağlantıların veya iklim adaletinin pratikte gerçekleştirilmesi için çalışan REDD (Reducing Emissions From Deforestation And Forest Degradation - Ormansızlaşma ve Orman Bozulmasına Bağlı Emisyonlarının Azaltılması) gibi mekanizmaların uygulanmasina dair analizler oldukça azdır" (Vanderheiden 2016, 27).

$\mathrm{Bu}$ küresel meselenin Trump gibi siyasi liderlere ya da BM gibi organlara birak1lamayacak olduğunun kabulü, daha radikal politikaların ve tabandan gelen sosyal hareketlerin gerekliliği olarak yorumlanabilir. Bir araya gelinerek alınan kararların uygulanması noktasındaki bitmek bilmeyen sıkıntı, küresel toplumu her geçen gün telafisi çok daha zor noktalara götürmektedir.

İklim adaletine ulaşılması bağlamında uluslararası toplum, iklim değişikliğinin etkileri sonucunda sosyo-ekonomik ve siyasi haksızlıklara maruz kalan savunmasız ülkelerin çatışmaya girmemesini sağlamak için iklim değişikliğine uyum konusundaki kararlılığını artırmalıdır. (Das 2016, 431-432). İklim adaletinin etkili olabilmesi için, iklim yönetişiminin makro seviyeyi (hükümetler arası ve uluslararası), mezo seviyeyi (bölgesel, ulusal ve yerel) ve mikro seviyeyi (belediye, yerel ve topluluk) içermesi gerekmektedir, ki bu da aşağıdan yukarıya politika stratejileri ve vizyonları ile aşağıdan yukarıya öğrenme süreçlerini ince bir biçimde ayarlamayı gerektirir (Huntjens \& Zhang 2016, 24). Tüm bu fikirler hali hazırda faaliyete geçmiş yahut planlanan politikaların, kalkınma programlarının ve finansman çabalarının sürdürülebilirliğini ve etkinliğini artırmak adına oldukça önemlidir.

\section{Sonuç}

İnsanın doğayı tahakküm altına alma ve onu dönüştürme çabası sonucunda iklim değişikliği, insanlığın ve gezegenin 21. yüzyılda karşı karşıya kaldığı en büyük tehdit haline gelmişsir. $\mathrm{Bu}$ küresel tehdit sadece çevresel felaketler, bunların geçim kaynakları ve insan sağlığı üzerindeki etkileri nedeniyle önemli değildir. Aslen, meydana gelme sebeplerinin günümüz toplumunun sosyo-ekonomik dokusuna işlemiş olması ve bazı toplumların refah düzeyi ile doğrudan bağlantılı olması nedeniyle de önem arz etmektedir. "İnsanın doğayı boyunduruk altına alma çabalarının tarihi, insanın insanı boyunduruk altına almasının da tarihidir. Ego, benlik kavramının gelişimi, bu iki yanlı tarihi yansıtır" (Horkheimer 1994, 128). İnsan-doğa ilişkisinin doğanın zararına ilerlediği yanılgısının idrakiyle birlikte karşı karşıya kalınan küresel iklim değişikliği tehdidi, insanlığın nezdinde doğanın yeniden konumlandırılma ihtiyacını doğurmuştur. Ancak bu sorun tüm çevresel, sosyal, demografik, ekonomik, siyasal, hukuksal yanları ve dahası zamansal ve mekânsal boyutlarıyla birlikte düşünüldüğünde, bugün insanlığın kendini de yeniden konumlandırma mecburiyeti ona doğa tarafından dayatılmaktadır. Kovel'in deyimiyle:

“...doğanın insani üretimi tamponlama kapasitesini sistemli bir biçimde tahrip eden ve en sonunda da aşan, böylelikle de ekosistemlerde nelere neden olacă̆ olan ve sürekli genişleyen bir dizi çöküşü başlatan yapısal güçlerin 
tarihin içinde bulunduğumuz aşamasına damgasını vurduğunu söyleyebiliriz. Bu evreden söz ederken ekolojik krizi kastediyoruz. Bu evrede hayat döngülerinin birbirleriyle uyumlu işleyişinin aksadiğını, canlı türleriyle bireylerin ilişkilerinin bozulduğunu, böylece insani ekosistemlerin olduğu kadar diğer ekosistemlerin de parçalandığını gözlemleriz. Zira insanlık krizin sadece faili değil, aynı zaman da kurbanıdır da. Krizle mücadele etmede yetersiz kalmamız, hatta varlığının bilincine dahi varmayışımı onun kurbanı olduğumuzun emareleridir" (Kovel 2017, 42-43).

"Doğa üzerindeki egemenlik, insan üzerindeki egemenliği getirir" (Horkheimer 1994, 120). Buzulların erimesi, deniz seviyesinin yükselmesi, şiddetli kuraklık, artan aşırı hava olayları vb. iklim değişikliği etkileri ve buna bağlı yaşanan başta sağlık ve gıda güvenliği tehditleri sonucu, insan-doğa ilişkisinde doğayı sömüren insanlık, bindiği dalı kestiğini fark edeli çok olmuştur. Ve fakat bunun da ötesinde, iklim değişikliği sonucu göç etmek zorunda kalacak olan milyonlarca insana dair ortaya konan (Suriyeli mülteciler ve Avrupa'da artan sağ yönelimi bağlantısı buna iyi bir örnektir) öngörüler, insanın insan üzerindeki sömürüsünde de bindiği dalı kestiğini fark etmesini bir an evvel sağlamalıdır. Bu nedenle iklim değişikliği bağlamında küresel eşitlik ve küresel adalet tartışmaları hiç olmadığı kadar önemli bir noktadır.

Tüm bu adalet talepleri onlarca yıl daha reddedilse dahi 1 rkçılık, cinsiyet ayrımcılığı ve eşcinsel haklarında olduğu gibi günün birinde zafer kazanılabilir (Jamieson 2015, 805). Ancak, bu sefer bunun bedelini tüm dünya insanları, yuvalarından olarak ödeyebilirler. Ne var ki, Martinez-Alier'in deyişiyle (2014, 386), “insanlık, insanlı̆̆ın Dünya'nın yüzünü bozarak jeolojik bir gü̧̈ haline geldiği dönemdir, ancak insanllk, yerel ve küresel direniş gelişimleriyle iklim değişikliğini durdurup, yaşamın çeşitliliğini ve zenginliğini tekrar yaratmaya yardım ettiği çă̆ da olabilir". Karbon salımlarıyla masum insanları öldürenlerin bombalar ve silahlarla öldürenler kadar katil olduğu, bir gün kabul edilebilir (Jamieson 2015, 795). İşte tam da bu nedenle iklim adaleti, adil ve yaşanılır yeni bir toplumsal düzenin doğum sancısı olabilir. 


\section{KAYNAKÇA}

Atay H. (2016). "Kapitalizmden Çıkış Denemesi, Cochabamba Halk Mücadelesi”. 6. Karaburun Bilim Kongresi'nde sunulmuş bildirinin "kısmen” düzeltilmiş hâlidir. 08-11 Eylül 2011, Karaburun/İzmir).

Bell D. (2010) "Ethics, Justice and Climate Change". Environmental Politics 19/3 (2010) 475-479. Kaynak: <https://doi.org/10.1080/09644016.2010.496956>.

Bond P. (2016). "Who Wins From "Climate Apartheid"? African Climate Justice Narratives About the Paris COP21”. New Politics 15/4 (2016) 83. Kaynak: <http://web.a.ebscohost.com/ehost/pdfviewer/pdf viewer?vid=0\&sid=031ffe0d-88d3-4056-b5f6-7157ceca331e\%40sessionmgr4007>.

Borovalı M. (2003). "Küresel Adalet Üzerine Bir Tartışma”. Eds. A. Kaya \& G. G. Özdoğan, Uluslararası İlişkilerde Sinır Tanımayan Sorunlar (2003) 219-332. Ankara.

Brown A. D. \& P. Taylor (Eds.) (2014). Ethics and Climate Change. A Study of National Commitments IUCN. Gland 2014. Source: <www.iucn.org/publications>.

Caney S. (2016). "The Struggle for Climate Justice in a Non-Ideal World". Midwest Studies in Philosophy 40/1 (2016) 9-26. Kaynak: <https://philpapers.org/archive/CANTSF-2.pdf>.

Claeys P. \& Delgado Pugley D. (2017). "Peasant and Indigenous Transnational Social Movements Engaging with Climate Justice". Canadian Journal of Development Studies 38/3 (2017) 325-340. Source: $<$ https://www.iss.nl/sites/corporate/files/CMCP_15-_Claeys__Delgado.pdf $>$.

Das O. (2016) "Climate Change and Armed Conflict: Challenges and Opportunities for Maintaining International Peace and Security Through Climate Justice”. Ed. R. S. Abate, Climate Justice: Case Studies in Global and Regional Governance Challenges (2016). Washington D.C. Available from $<\mathrm{http}$ ://eprints.uwe.ac.uk/30412>.

Demirci M. (2013). “İklim Değişikliği ve Dağıtıcı Adalet”. Eskişehir Osmangazi Üniversitesi İktisadi ve Ídari Bilimler Dergisi 8/2 (2013). Kaynak: <http://dergipark.ulakbim.gov.tr/eoguiibfd/article/view File/5000074845/5000069143>.

Fisher S. (2015). "The Emerging Geographies of Climate Justice". The Geographical Journal 181/1 (2015) 73-82. Source: <http://www.lse.ac.uk/GranthamInstitute/wp-content/uploads/2014/02/WP83emerging-geographies-climate-justice.pdf $>$.

Foster J. B. (2012). Marksist Ekoloji. Çev. B. Baysal. İstanbul 2004.

Gardiner S. M. (2004). "Ethics and Global Climate Change". Ethics 114/3 (2004) 555-600. Source: $<\mathrm{http}$ //www.jstor.org/stable/10.1086/382247>

Guglyuvatyy E. (2017). "Climate Justice for A Global Treaty: An Australian Perspective”. Carbon \& Climate Law Review 1/2017 (2017) 50-63. Source: <http://heinonline.org/HOL/P?h=hein.journals/cclr $2017 \& \mathrm{i}=56>$.

Harris P. G. (2010). World Ethics and Climate Change: From International to Global Justice: From International to Global Justice. Edinburgh 2010. Source: <https://books.google.com.tr/books?hl= tr\&lr $=\& \mathrm{id}=\mathrm{hRarBgAAQBAJ} \& \mathrm{oi}=\mathrm{fnd} \& \mathrm{pg}=\mathrm{PR} 5 \& \mathrm{dq}=$ World + ethics + and + climate + change: + from + intern ational + to + global + justice \&ots $=$ HaTJn66T-W\&sig=8Jylt41JpXO7bdQM1XJuBO8WnhM\&redir esc $=y$ $\# \mathrm{v}=$ onepage $\& \mathrm{q}=$ World $\% 20$ ethics $\% 20$ and $\% 20$ climate $\% 20$ change $\% 3 \mathrm{~A} \% 20$ from $\% 20$ international $\% 20$ to $\% 20$ global $\% 20 j$ ustice \&f $=$ false $>$.

Horkheimer M. (1994). Akıl Tutulması. Çev. O. Koçak. İstanbul 1994.

Huntjens P. \& Zhang T. (2016). "Climate Justice: Equitable and Inclusive Governance of Climate Action". The Hague Institute, Working Paper, 16 April. Source: <http://www.thehagueinstitute forglobaljustice.org/wp-content/uploads/2016/04/Climate-Justice-April-2016.pdf>.

Jamieson D. (2015). “Two Cheers for Climate Justice”. Social Research: An International Quarterly 82/3 (2015) 791-809. Source: <https://pdfs.semanticscholar.org/4cbb/222375939c087c0ac46d5b9b26c5a81 07928.pdf>.

Kovel J. (2017). Doğanın Düşmanı: Kapitalizmin Sonu Mu, Dünyanın Sonu Mu?. Çev. G. Koca. İstanbul 2017.

Lahn B. (2018). "In the Light of Equity and Science: Scientific Expertise and Climate Justice After Paris". International Environmental Agreements: Politics, Law and Economics 18/1 (2018) 29-43. $<$ https://doi.org/10.1007/s10784-017-9375-8>. 
Lovelock J. (2006). The Revenge of Gaia: Earth's Climate in Crisis and the Fate of Humanity. New York City 2006.

Martinez-Alier J. (2015). "Climate Justice". Development and Change 46/2 (2015) 381-386. Doi: $10.1111 /$ dech. 12150

Mason M. (2011). "The Ends of Justice: Climate Vulnerability Beyond the Pale". The Governance of Climate Change: Science, Politics, Ethics, Polity (2011) 162-182. Cambridge. Source: $<$ http://eprints.lse.ac.uk/36656/>.

McKinney L. A. \& Fulkerson G. M. (2015). "Gender Equality and Climate Justice: A Cross-National Analysis”. Social Justice Research 28/3 (2015) 293-317. Doi: <https://doi.org/10.1007/s11211-0150241-y>.

Özlüer M. F., Özlüer I. Ö., Şirin T. \& Odabaşı N. S. (2013). Bolivya Anayasası: Hukuk, Demokrasi, Özerklik. 2013.

Preston I., Banks N., Hargreaves K., Kazmierczak A., Lucas K., Mayne R., Downing C. \& Street R. (2014). "Climate Change and Social Justice: An Evidence Review". Joseph Rowntree Foundation, Centre for Sustainable Energy. Source: <http://www.cse.org.uk/app/webroot/ downloads/file/climate $\% 20$ change $\% 20$ and $\% 20$ social $\% 20$ justice $\% 20$ evidence $\% 20$ review.pdf $>$.

Radkau J. (2017). Doğa ve İktidar: Global Bir Çevre Tarihi. Çev. N. Güder. İstanbul 2017.

Rawls J. (1971). A Theory of Justice-Original Edition. London 1971.

Reese G. (2015). "Common Human Identity and the Path to Global Climate Justice". Climatic Change 134/4 (2015) 521-531. Doi: <https://doi.org/10.1007/s10584-015-1548-2>.

Schmidt A. (2012). "Justice in the Public Climate Debate". 24 $4^{\text {th }}$ International Climate Policy PhD Workshop in Freiburg. Source: <https://www.researchgate.net/profile/Andreas_Schmidt2/publication /236870172_Justice_in_the_Public_Climate_Debate_Claims_Related_Policy_Preferences_in_Comp arative_Perspective/links/0c960519bd1d49ec46000000/Justice-in-the-Public-Climate-Debate-Claims -Related-Policy-Preferences-in-Comparative-Perspective.pdf $>$.

Sealey-Huggins L. (2017). " $1.5^{\circ} \mathrm{C}$ to Stay Alive': Climate Change, Imperialism and Justice for the Caribbean". Third World Quarterly 38/11 (2017) 2444-2463. Doi: <https://doi.org/10.1080/01436 597. 2017.1368013>.

Steele W., Mata L. \& Funfgeld H. (2015). "Urban Climate Justice: Creating Sustainable Pathways for Humans and Other Species". Current Opinion in Environmental Sustainability 201514 (2015) 121126. Doi: <http://dx.doi.org/10.1016/j.cosust.2015.05.004>.

Sweetman J. \& Whitmarsh L. E. (2016). "Climate Justice: High-Status Ingroup Social Models Increase Pro Environmental Action Through Making Actions Seem More Moral”. Topics in Cognitive Science 8/1 (2016) 196-221. Doi: <10.1111/tops.12178>.

Uprimny R. (2012). "Latin Amerika'da Yeni Anayasa Hukuku Dönüşümleri: Eğilimler ve Sorunlar". Küresel Bakış 2/5 (2012 Nisan).

Vanderheiden S. (2008). Atmospheric Justice: A Political Theory of Climate Change. OUP USA. Kaynak: $<$ https://books.google.com.tr/books?hl=tr\&lr=\&id=cItxZHGUywUC\&oi=fnd\&pg=PR7\&dq=Atmosp heric + justice + a + political + theory + of + climate + change \&ots $=$ RoF_dJXKM\&sig $=U$ UJaKFHkwmLyCj VKw1VsImk2D2Y\&redir_esc=y\#v=onepage\&q=Atmospheric\%20justice $\% 3 \mathrm{~A} \% 20 \mathrm{a} \% 20$ political\%2 0 theory $\% 20$ of $\% 20$ climate $\% 20$ change $\& \mathrm{f}=$ false $>$.

Vanderheiden S. (2016). "Climate Justice Beyond International Burden Sharing". Midwest Studies in Philosophy 40/1 (2016) 27-42. Source: <http://sciencepolicy.colorado.edu/admin/publication_files /2016.18.pdf>.

White-Newsome J. L. (2016). "A Policy Approach Toward Climate Justice”. The Black Scholar 46/3 (2016) 12-26. Doi: <http://dx.doi.org/10.1080/00064246.2016.1188353>. 